O. DARIUSZ BOREK OCarm

Wydział Prawa Kanonicznego

Uniwersytetu Kardynała Stefana Wyszyńskiego w Warszawie

ORCID: 0000-0002-9975-4309

\title{
PRZERWANIE BIEGU PRZEDAWNIENIA SKARGI KRYMINALNEJ W KANONICZNYM PROCESIE KARNYM
}

Treść: Wstęp. - 1. Przerwanie i zawieszenie biegu przedawnienia - uwagi ogólne. - 2. Różne stanowiska dotyczące momentu, w którym następuje przerwanie biegu przedawnienia. - 3. Dekret i wyrok skazujący jako moment przerwania biegu przedawnienia. - Wnioski.

\section{Wstęp}

Przedawnienia należy do tych zagadnień, którym kanonistyka, do pewnego czasu, poświęcała stosunkowo niewiele miejsce'. Taki stan rzeczy dotyczy również przerwania biegu przedawnienia. Należy zauważyć, że przerwanie (i tym bardziej zawieszenie ${ }^{2}$ ) biegu prze-

${ }^{1}$ Zob. D. Borek, Przedawnienie skarg i działań z tytułu naruszeń będących przestępstwami kanonicznymi, Prawo Kanoniczne 62(2019) nr 3, s. 55-88.

${ }^{2}$ W doktrynie kanonistycznej odnoszącej się do KPK/1983 właściwie nie spotykamy się z takimi terminami jak zawieszenie czy spoczywanie biegu przedawnienia skargi kryminalnej. Zob. min. J. Syryjczyk, Sankcje w Kościele. Część ogólna. Komentarz, Warszawa 2008, s. 319-327; B.F. PIGHIN, Diritto penale canonico, Venezia 2008, s. 282-290. Wynika to zapewne $z$ tego, że KPK/1983 nigdzie nie wspomina o zawieszeniu/spoczywaniu biegu przedawnienia. Wprawdzie mówi się o zawęszeniu wyroku lub dekretu (kan. 1353), kary (kan. 1352), obowiązku przestrzegania kary (kan. 1344, n. 3), cenzury (kan. 1335), niemniej jednak nie dotyczy to samego biegu przedawnienia. 
dawnienia to zagadnienia raczej mało wyeksponowane, zarówno na płaszczyźnie kanonicznego prawa karnego materialnego jak i formalnego. W kontekście stosunkowo krótkich terminów przewidzianych aktualnie dla przedawnienia actio criminalis $^{3}$, istotnego znaczenia nabiera kwestia dotycząca ewentualnego przerwania i/lub zawieszenia biegu przedawnienia.

Należy zauważyć, że w dotychczasowej kanonistyce możemy znaleźć różne opinie dotyczące tego, kiedy właściwie następuje przerwanie biegu przedawnienia ${ }^{4}$. Taki brak spójności w opiniach doktryny kanonistycznej zmusza do podjęcia próby udzielenia odpowiedzi na następujące pytania: czy w kanonicznym prawie karnym materialnym i formalnym przewidziane jest przerwanie i/lub zawieszenie biegu przedawnienia, a jeśli tak, to w jakim dokładnie momencie ono następuje i jakie z tego wynikają skutki.

Próbując udzielić odpowiedzi na wyżej postawione pytanie, niezbędne wydaje się skoncentrowanie uwagi na następujących głównych zagadnieniach: przerwanie i zawieszenie - uwagi ogólne; różne stanowiska dotyczące momentu, w którym następuje przerwanie biegu przedawnienia; dekret/wyrok skazujący jako moment przerwania biegu przedawnienia.

\footnotetext{
${ }^{3}$ Stwierdzenie to, mając na uwadze treść kan. $1363 \$ 1-2$, dotyczy także terminów przedawnienie actio poenalis. Warto w tym miejscu zauważyć, że systemy państwowe znają jeszcze instytucję przedawnienia wyrokowania, czyli czasokres, w obrębie którego postępowanie ulega przedawnieniu, zob. Polski kodeks karny art. 104. Zob. także M. MYrchA, dz.cyt., s. 764 . Polski kodeks karny z 1997 roku przewiduje przedawnienie karalności (art. 101 k.k.) oraz przedawnienie wykonania kary (art. 103 k.k.). Niemniej jednak i w tym przypadku można mówić o podziale na trzy rodzaje przedawnienia - ścigania, wyrokowania i wykonania kary - z tym że przedawnienie ścigania jest ujęte łącznie z przedawnieniem karalności. Por. M. Bojarski, J. Giezek, Z. Sienkiewicz, Prawo Karne materialne. Czesść ogólna i szczegółowa, Warszawa 2006, s. 366; 369-370.

${ }^{4}$ Zresztą także i w dobie obowiązywania KPK/1917 nie było w tej kwestii jednomyślności, zob. M. Myrcha, Prawo karne. Kara, tom II, Warszawa 1960, s. 763-828.
} 


\section{Przerwanie i zawieszenie biegu przedawnienia - uwagi ogólne}

Przedawnienie w kanonicznym prawie karnym oznacza wygaśnięcie prawa karania przysługującego władzy w odniesieniu do konkretnej osoby, która popełniła przestępstwo. Zasadniczym motywem przedawnienia jest tutaj upływ czasu liczony od chwili popełnienia przestępstwa. Jeśli, zatem w czasie określonym przez prawo, nie dojdzie do ukarania sprawcy, to w takim razie wygasa karalność przestępstwa ${ }^{5}$. Przedawnienie, a właściwie jego bieg, może jednak ulec przerwie lub zawieszeniu. Chodzi tutaj o to, aby z jednej strony nie dopuścić do ewentualnej bezkarności sprawców przestępstw, ale z drugiej strony natomiast, aby nie dochodziło do przedłużania w nieskończoność (ad infinitum) możliwości karania ${ }^{6}$.

Przerwa przedawnienia oznacza zatrzymanie biegu przedawnienia, którego skutkiem jest anulowanie czasu, jaki upłynął do zaistnienia przyczyny skutkującej przerwaniem. Innymi słowy stukiem przerwy (dla przedawnienia ścigania) okres wymagany dla prawnego przedawnienia, należałoby zacząć liczyć od nowa od momentu ustania przerwy ${ }^{7}$. Jeśli zatem w dniu oznaczonym literą B nastąpi przerwa biegu przedawnienia, to znaczy, że całkowicie zostaje anulowany czas, jaki do tej pory upłynął od punktu A, to znaczy od terminu a quo. W konsekwencji po ustaniu przyczyny powodującej przerwę, tj. od dnia oznaczonego literą C, bieg przedawnienia zacznie się liczyć od nowa ${ }^{8}$. $Z$ kolei zawieszenie przedawnienia to okoliczność prawna lub faktyczna, nie pozwalająca na wszczęcie postępowania sądowego lub na dalsze prowadzenie go. Skutkiem takiego zawieszenia jest to, że czas, który upłynął przed zaistnieniem zdarzenia powodującego spoczywanie, dolicza się do czasu, jaki zacznie biec po ustaniu przyczyny

\footnotetext{
${ }^{5}$ Zasadniczo możemy mówić o trzech rodzajach przedawnienia o: przedawnieniu ścigania; przedawnieniu wykonania kary; przedawnieniu wyrokowania. Por. M. Myrcha, dz. cyt., s. 763-764.

${ }^{6}$ Por. tamże, s. 765-767.

${ }^{7}$ Tamże, s. 765-766.

${ }^{8}$ Por. L. Llobell, Sull'interruzione e sulla sospensione della prescrizione dell'azione penale, Ius Ecclesiae 25 (2013), s. 647.
} 
zawieszenia ${ }^{9}$. Zasadnicza różnica pomiędzy przerwą a zawieszeniem przedawnienia polega zatem na tym, że przy przerwie przedawnienia czas, który upłynął przedtem, przepada, a przy zawieszeniu przedawnienia dolicza się go do czasu, który zacznie biec po ustaniu przyczyny spoczywania przedawnienia ${ }^{10}$.

Zgodnie z powyższym, instytucja przerwy wydaje się być zdominowana przez ius puniendi, ponieważ skutkuje ona wydłużeniem czasokresu, w którym actio criminalis i actio poenalis będą mogły być realizowane względem sprawców przestępstw. Natomiast instytucja zawieszenia wydaje się być bardziej nastawiona na zrównoważenie napięcia pomiędzy favor rei i ius puniendi. Otóż zawieszenie, z jednej strony ewidentnie ma na względzie korzyść oskarżonego, ale $\mathrm{z}$ drugiej bierze pod uwagę także ius puniendi. Po pierwsze, chodzi bowiem o czas, w którym uprawniony do działania podmiot (posiadający actio criminalis lub actio poenalis) nie może wykonywać przysługującego mu prawa, ponieważ oskarżony jest chroniony np. prawem azylu ${ }^{11}$. W takiej sytuacji bieg przedawnienia zostaje nie tylko że zawieszony (spoczywa), ale jednocześnie nie ulega wyzerowaniu, o czym była mowa powyżej. Z drugiej jednak strony, na zawieszenie można spojrzeć także i z perspektywy realizacji ius puniendi, czy też actio poenalis, a nie ochrony oskarżonego. Chodzi bowiem o to, że po ustaniu przyczyny skutkującej zawieszeniem przedawnienia, czas biegnie dalej sumując się z tym, który już upłynął wcześniej. Po ustaniu przyczyny zawieszenia następuję bowiem kontynuacja biegu czasu, który został zawieszony. Innymi słowy, licznik biegnie dalej od tego momentu, w którym został zatrzymany. Wydaje się, że właśnie takie rozwiązanie sprawy najlepiej godzi ze sobą te dwa

\footnotetext{
${ }^{9}$ Por. tamże, s. 647.

${ }^{10}$ M. Mrrcha, dz.cyt., s. 763-767.

${ }^{11} \mathrm{~W}$ historii takie prawo azylu było przewidziane w przypadku ucieczki do jakiegoś klasztoru albo w statusie uchodźcy na płaszczyźnie prawa narodowego i międzynarodowego. Por. L. Llobell, dz. cyt., s. 647. Zgodnie z Polskim kodeksem karnym spoczywanie biegu przedawnienia jest możliwe jedynie z powodu przeszkód natury prawnej. Por. k.k. art. 104. Zob. także M. BojArski, J. Giezek, Z. Sienkiewicz, dz. cyt., s. 370 .
} 
aspekty favor rei i konieczność ochrony bonum commune Ecclesiae poprzez ius puniendi. Wspomniany favor rei domaga się przedawnienia skargi kryminalnej, w myśl biblijnego pojęcia jubileuszu ${ }^{12}$, oczywiście z wyjątkiem najcięższych przypadków zastrzeżonych dla Kongregacji Nauki Wiary, czy też godzących w ludzkość. Niemniej jednak należy mieć na uwadze także i to, że ze względu na bonum commune Ecclesiae, nie można dopuścić do takiej sytuacji, kiedy sprawca nie zostałby pociągnięty do odpowiedzialności za przestępstwa powodujące szczególną szkodę ofiarom i społeczności Kościoła, jedynie z tego powodu, iż możliwość ich ścigania uległa już przedawnieniu $\mathrm{z}$ powodu zbyt krótkich terminów przedawnienia ${ }^{13}$.

Należy zauważyć, że w prawie kanonicznym nie przewiduje się właściwie instytucji zawieszenia biegu przedawnienia actio criminalis i actio poenalis ${ }^{14}$. Ponadto, także i w odniesieniu do ewentualnej przerwy biegu przedawnienia ww. skarg, prawo kanoniczne nie przewiduje właściwie konkretnych dyspozycji, szczególnie takich które byłyby zawarte w części dotyczącej kanonicznego prawa karnego materialnego i formalnego. Należy sobie zatem zadać pytanie odnośnie do tego, czy faktycznie w kanonicznym prawie karnym (materialnym i formalnym) przewidziana jest przerwa biegu przedawnienia actio criminalis i actio poenalis, a jeśli tak, to dokładnie $\mathrm{w}$ jakim momencie ona następuje.

\section{Różne stanowiska dotyczące momentu, w którym następuje przerwanie biegu przedawnienia}

Próbując udzielić odpowiedzi na podstawowe zagadnienie obecnego artykułu należy przypomnieć, że kanoniczny proces karny nie jest czymś zupełnie autonomicznym, wręcz przeciwnie można mówić

\footnotetext{
${ }^{12} \mathrm{Kpł} 25,8-17$ i nn.

${ }^{13}$ Por. L. Llobell, dz. cyt., s. 647-648.

${ }^{14}$ Zawieszenie biegu przedawnienia było właściwie przewidziane w tzw. Dekrecie lubelskim. Otóż w przypadku przestępstwa, które było całkowicie tajne, okres przedawnienia zaczynał biec dopiero od dnia, w którym przestępstwo stało się jawne dla oskarżyciela lub prowadzącego śledztwo. Zob. ASS 30(1897-1899), s. 677-689.
} 
o swego rodzaju nieautonomiczności kanonicznego procesu karego. Tak naprawdę proces karny nie jest czymś autonomicznym, gdyż w rzeczywistości istnieje jedna procedura administracyjna i jeden proces sporny zwyczajny z pewnymi specyficznymi elementami dla spraw dotyczących wymierzania i deklarowania kar kościelnych ${ }^{15}$. O takim stanie rzeczy świadczy po pierwsze konieczność stosowania w procesie karnym na drodze sądowej nisi rei natura obstet: kanonów o procesie w ogólności; kanonów dotyczących procesu spornego zwyczajnego; norm specjalnych przewidzianych dla spraw dotyczących dobra publicznego ${ }^{16}$. Następnie, konieczność aplikowania dyspozycji zawartej w kan. 1728 także do procesu na drodze administracyjnej ${ }^{17}$, zawsze zachowując przepisy kanonów tego tytułu, oczywiście nisi rei natura obstet. I w końcu, konieczność stosowania w procesie na drodze administracyjnej przepisów dotyczących procedury jaką należy zachować przy wydawaniu konkretnych aktów administracyjnych a w szczególności konkretnych dekretów i ewentualnego wnoszenia rekursów ${ }^{18}$.

W procesie karnym na drodze sądowej należy stosować kanony o sądach w ogólności (kan. 1400-1500), a zatem przepisy dotyczące: właściwości sądu; różnych stopni i rodzajów trybunałów; zasad

\footnotetext{
${ }^{15}$ Por. C. Papale, Il processo penale canonico. Commento al Codice di Diritto Canonico. Libro VII, Parte IV, Città del Vaticano 2012, s. 42 i przypis n. 117. Zob. także R. Coppola, La tutela dei diritti nel processo penale canonico, w: Studi Giuridici 18, Il diritto alla difesa nell'ordinamento canonico, Città del Vaticano 1988, s. 75.

${ }^{16} \mathrm{KPK} / 1983$, kan. 1728. Wspomniana w kan. 1728 rei natura to specjalne dyspozycje dotyczące kanonicznego procesu karnego oraz dobra publicznego, które znajdują się w różnych miejscach Księgi VII KPK/1983. Jednym ze specyficznych przykładów jest zakaz domagania się od oskarżonego złożenia przysięgi (KPK/1983, kan. $1728 \$ 2 ; 1368)$, podczas gdy zgodnie z kan. 1532 sędzia powinien nakazać złożenie przysięgi w sprawach, które dotyczą dobra publicznego. Zob. KPK/1983, kan. 1562 $\$ 2$.

${ }^{17}$ Wydaje się, że nic nie stoi na przeszkodzie, aby powyższa dyspozycja miała zastosowanie także do procesu karnego na drodze administracyjnej. Por. C. PAPAlE, Il processo penale canonico..., s. 42.

${ }^{18}$ KPK/1983, kan. 35-58; kan. 1732-1739.
} 
działania trybunałów; stron w sprawie; skarg i zarzutów ${ }^{19}$. Ponadto należy stosować także kanony o zwykłym procesie spornym (kan. 1501-1655), czyli: wprowadzenie sprawy; zawiązanie sporu; instancja sporu; dowody; sprawy wpadkowe; ogłoszenie akt, zamknięcie postępowania dowodowego, dyskusja sprawy; orzeczenie sędziego; zaskarżenie wyroku; stan rzeczy osądzonej i przywrócenie do stanu poprzedniego; koszty sądowe i bezpłatna pomoc; wykonanie wyroku ${ }^{20}$. W kan. 1328 nic się nie mówi o ustnym procesie spornym (kan. 16561670), dlatego też można przyjąć, że jest on wykluczony. To, że w kan. 1725 mówi się o możliwości ustnej dyskusji, nie świadczy jeszcze o tym, że mamy tutaj odniesienie do ustanego procesu spornego.

${ }^{19} \mathrm{~W}$ sposób szczególny należy mieć na uwadze przykładowo następujące dyspozycje: kan. $1400 \$ 1$, n. 2 - określający, że przedmiotem procesu karnego są przestępstwa w tym, co dotyczy wymierzenia lub deklaracji kary; kan. 1401, n. 2 - wskazujący na własną i wyłączną władzę Kościoła rozpoznawania naruszeń ustaw kościelnych oraz wszystkich innych, w których ma miejsce grzech, w tym, co dotyczy ustalenia winy i wymierzenia kar kościelnych; kan. 1405 - dotyczący spraw zarezerwowanych dla papieża lub Roty Rzymskiej; kan. 1412 - przewidujący, że w sprawach karnych oskarżony, chociażby nieobecny, może być pozwany przed trybunał miejsca, w którym dokonano przestępstwa (forum delicti comissi); kan. $1425 \$ 1$, n. 2 - rezerwujący dla trybunału złożonego $\mathrm{z}$ trzech lub pięciu sędziów sprawy karne dotyczące przestępstw, za które jest przewidziana kara wydalenia ze stanu duchownego oraz wymierzenie lub deklarowanie kary ekskomuniki; kan. 1452 - dotyczący inicjatywy sędziego, który, w sprawach karnych i związanych z dobrem publicznym lub zbawieniem dusz, może i powinien postępować także z urzędu (oczywiście już po legalnym wniesieniu sprawy); kan. $1455 \$ 1$ - nakładający w sprawach karnych obowiązek bezwzględnego zachowania tajemnicy przez sędziów i pomocników trybunału.

${ }^{20} \mathrm{~W}$ sposób szczególny należałoby mieć na uwadze przykładowo następujące dyspozycje: kan. 1554 - nakładający na sędziego obowiązek podania do wiadomości stron imion świadków przed ich przesłuchaniem; kan. 1559 - zgodnie z którym w sprawach dotyczących dobra publicznego strony nie mogą uczestniczyć w przesłuchaniach świadków (natomiast adwokaci i pełnomocnicy stron mogą być dopuszczeni do takich przesłuchań, ale sędzia może na nich nałożyć obowiązek złożenia przysięgi zachowania tajemnicy - kan. $1455 \$ 3$ ). Należy w tym miejscu zaznaczyć, że osoba donosząca o przestępstwie nie jest stroną w procesie karnym. 
Mamy tutaj bowiem do czynienia z elementem przewidzianym także w czasie zwykłego procesu spornego ${ }^{21}$.

Zgodnie z powyższym, w kanoniczym procesie karnym na drodze sądowej należy mieć na uwadze także i to, co się przewiduje w kan. 1512, a mianowicie: „Cum citatio legitime notificata fuerit aut partes coram iudice steterint ad causam agendam: $1^{\circ}$ res desinit esse integra; $2^{\circ}$ causa fit propria illius iudicis aut tribunalis ceteroquin competentis, coram quo actio instituta est; $3^{\circ}$ in iudice delegato firma redditur iurisdictio, ita ut non expiret resoluto iure delegantis; $4^{\circ}$ interrumpitur praescriptio, nisi aliud cautum sit; $5^{\circ}$ lis pendere incipit; et ideo statim locum habet principium <lite pendente, nihil innovetur>". W kontekście omawianego w niniejszym artykule zagadnienia należy zwrócić uwagę na numer czwarty cytowanego kanonu, według którego po zawiadomieniu o pozwie zgodnie z przepisami prawa, albo gdy strony stawiły się przed sędzią w celu prowadzenia sprawy: przedawnienie ulega przerwaniu, chyba że co innego zostało zastrzeżone.

W związku z powyższym powstaje pytanie, czy zatem, w myśl zacytowanego kan. 1512 n. 4, bieg przedawnienia actio criminalis zostaje przerwany na skutek wezwania sądowego lub dobrowolnego stawienia się stron w sądzie? Warto jednakże zauważyć, że nie mniej uzasadnione wydaje się być pytanie odnośnie tego, co z biegiem przedawnienia w następujących sytuacjach: w momencie wszczęcia dochodzenia wstępnego (kan. 1717); w momencie wszczęcia procesu karnego na drodze administracyjnej lub sądowej (kan. $1718 \$ 1$, n. 3; 1720; 1721); z chwilą pierwszego aktu ściśle procesowego a mianowicie wniesienia skargi oskarżającej (kan. 1504 i 1721 \$ 1); oraz w momencie uprawomocnienia się dekretu/wyroku (kan. 1720, n. 3 i kan. 1726).

Jak to już zostało zaznaczone wcześniej, ani w części materialnej kanonicznego prawa karnego, ani w części poświęconej bezpośrednio kanonicznemu procesowi karnemu, nic się nie mówi wprost o przerwaniu biegu przedawnienia. Być może to właśnie m.in. z tego powodu w kanonistyce można było w tej kwestii spotkać różne opinie.

\footnotetext{
${ }^{21}$ Por. Z. Suchecki, Il processo penale giudiziale, w: Il processo penale canonico, a cura di Zbigniew Suchecki, Roma 2003, s. 250-252.
} 
Według jednej z nich, bieg przedawnienia zostaje przerwany na skutek wezwania sądowego lub dobrowolnego stawienia się stron w sądzie. Podstawę do takiego twierdzenia stanowi dyspozycja, jaką znajdujemy w kan. 1512 n. 4: „Cum citatio legitime notificata fuerit aut partes coram iudice steterint ad causam agendam: (...) $4^{\circ}$ interrumpitur praescriptio, nisi aliud cautum sit (...)". W zacytowanym kanonie jest mowa ogólnie o przedawnieniu, a zatem autorzy przyjmowali, że także i o przedawnieniu actio criminalis. Zgodnie z powyższym, po zawiadomieniu o pozwie zgodnie z przepisami prawa albo gdy strony stawiły się przed sędzią $\mathrm{w}$ celu prowadzenia sprawy, bieg przedawnienia ulega przerwaniu ${ }^{22}$. Inni autorzy z klei, w oparciu kan. 1502 i kan. $1721 \S 1$, utrzymywali że bieg przedawnienia zostaje przerwany z chwilą pierwszego aktu ściśle procesowego a mianowicie skargi oskarżającej ${ }^{23}$. Należy jednakże zauważyć, że kan. 1502 mówi jedynie o konieczności wniesienia skargi powodowej, która winna być zredagowana według kan. 1504. Z kolei z treści kan. $1721 \S 1$ wynika, że skarga oskarżająca poprzedza wezwanie skierowane do oskarżonego. Wydawałoby się zatem, że należałoby tutaj przyznać rację pierwszej z wymienionych powyżej opinii, tzn. odnoszącej się do dyspozycji kan. 1512, n. 4. Warto w tym miejscu przypomnieć, że zgodnie z kan. 1512 n. 4, po zawiadomieniu o pozwie przedawnienie owszem ulega

\footnotetext{
${ }^{22}$ J. Syry JCZyk, Sankcje w Kościele..., s. 325. To samo stanowisko prezentowali także inni autorzy m.in. D.G. Astigueta, Delitti imprescrittibili nella Chiesa?, Periodica 101 (2012), s. 118. Zatem nie brakuje autorów, którzy przyjmowali iż efektem wezwania sądowego jest właśnie przerwa biegu przedawnienia. Taką tezę przyjmował także J.L. Sánchez Girón. Por. J.L. SÁnChez Girón, Algunos interrogantes en la disciplina codicial sobre la prescripción de la acción criminal, w: Iustitia et iudicium, vol. 4, s. 2178-2179, przypis n. 20.

${ }^{23}$ Por. D. Ciтo, La prescrizione in materia penale, w: Processo penale e tutela dei diritti nell'Ordinamento canonico, a cura di D. Cito, Milano 2005, s. 225, przypis n. 11; D. Ciтo, Prescription in penal matters, w: The penal proces and the protection of rights in canon law, ed. P.M. Dugan, Montréal 2005, s. 194. Zob. także, D.G. AstiGUETA, dz.cyt., s. 118, przypis n. 1; D. BoREK, Uprawnienia i obowiązki ordynariusza w początkowej fazie wymiaru kar (kann. 341-1342), Prawo Kanoniczne 50 (2007) nr 3-4, s. 246.
} 
przerwaniu nisi aliud cautum sit, a zatem o ile nie zostało zastrzeżone co innego ${ }^{24}$.

Wydaje się, że owa klauzula zastrzegająca możliwość innego rozwiązana została zawarta w tym, co się przewiduje w kan. 1726 oraz w kan. 1720, n. 3. Otóż na podstawie przywołanych kanonów można stwierdzić, że przedawnienie biegnie właściwie cały czas, aż do momentu uprawomocnienia się wyroku bądź dekretu. Co oznaczałoby, że żadna z uprzednio dokonanych czynności - przed procesowych i procesowych - nie powoduje przerwy biegu przedawnienia. Z treści kan. 1726 wynika bowiem, że „in quolibet poenalis iudicii gradu et stadio" może nastąpić przedawnienie actio criminalis et poenalis. Zatem należy przyjąć, że w procesie karnym na drodze sądowej przerwa biegu przedawnienia nie następuje, ani poprzez wniesienie skargi oskarżającej, ani w wyniku wezwania oskarżonego. Mamy tutaj zatem do czynienia z zastrzeżeniem, o którym mowa w kan. 1512, n. 4. Podobnie rzecz ma się z procesem karnym na drodze administracyjnej. Otóż w myśl kan. 1720 n. 3, ordynariusz powinien wydać dekret, jeśli przestępstwo z pewnością stwierdzono a skarga kryminalna nie wygasła. Innymi słowy ustawodawca kodeksowy, przewidując możliwość stwierdzenia przedawnienia skargi kryminalnej na każdym stopniu i etapie procesu karnego, wprowadza właśnie to zastrzeżenie, o którym mowa w kan. 1512, n. 4. Taka interpretacja omawianego zagadnienia wydawałaby się słuszna w kontekście przyjętych przez ustawodawcę Kodeksowego z 1983 łagodnych rozwiązań na rzecz sprawców przestępstw kanonicznych ${ }^{25}$. Warto jednakże zwrócić uwagę na to, że w kan. 1512, n. 4 jest raczej nawiązanie do przedawnienia jako nabycia prawa lub uwolnienia się od zobowiązania, a jak

\footnotetext{
${ }^{24} \mathrm{Za}$ taką interpretacją przemawiałoby także i to, że działania podejmowane przez inne organy władzy mają jedynie charakter przygotowawczy - jak w przypadku dochodzenia wstępnego, lub tylko administracyjny - jak w przypadku procesu karnego na drodze administracyjnej. M. МүгснA, dz.cyt., s. 766; D. Cito, Questioni sulla prescrizione dell'azione criminale /art. 7 m.p. Sacramentorum sanctitatis tutela/, w: Quaderni di Ius Missionale, La procedura nei delitti riservati alla Congregazione per la Dottrina della Fede, a cura di Papale Claudio, Città del Vaticano 2018, s. 39.

${ }^{25}$ Por. J. Llobell, dz. cyt., s. 655-656.
} 
wiadomo w takich przypadkach wymagana jest dobra wiara ${ }^{26}$. Wraz $\mathrm{z}$ wezwaniem do sądu, staje się rzeczą jasną, że owa bona fide przestaje istnieć. W przypadku przedawnienia actio criminalis i actio poenalis taka dobra wiara nie jest wymagana. Zatem kan. 1512, n. 4 nie może być aplikowany do spraw karnych. Taka sytuacja oznaczałaby, że ustawodawca kodeksowy z 1983 roku nie przewidział żadnej dyspozycji, która bezpośrednio czy też pośrednio odnosiłaby się do instytucji przerwy biegu przedawnienia actio criminalis i actio poenalis. Tym samym mamy tutaj do czynienia z luką w prawie, która - ze względu na rosnące znaczenie kanonicznego prawa karnego materialnego i formalnego - wymagałaby uzupełnienia przez ustawodawcę ${ }^{27}$. W konsekwencji należy przyjąć, że w procesie karnym na drodze sądowej oraz administracyjnej, przedawnienie płynie nieprzerwanie aż do momentu końcowego jakim jest wydanie wyroku/dekretu skazującego, który przeszedł w stan rzeczy osądzonej ${ }^{28}$.

Czas przedawnienia skargi kryminalnej, to czas ciągły (tempus continuum), czyli taki, który płynie nieprzerwanie, także przez cały czas dochodzenia wstępnego a następnie aż wydania wiążącego wyroku lub dekretu skazującego w procesie karnym. Bieg przedawnienia

${ }^{26}$ KPK/1983, kan. 198.

${ }^{27}$ Wprawdzie ustawodawca kościelny, w związku z promulgacją m.p. Sacramentorum sanctitatis tutela w 2001 roku zajął się kwestią przedawnienia, ale bez wyraźnego sprecyzowania kwestii odnoszących się do przerwy biegu przedawnienie i wynikających z tego skutków. Por. J. Llobell, dz. cyt., s. 645-646.

${ }^{28}$ Por. J. Llobell, dz. cyt., s. 654. Biorąc pod uwagę argumenty prawne, jakie przytacza J. Llobell, należy zgodzić się z jego stanowiskiem w sprawie momentu, w którym następuje przerwa biegu przedawnienia. Zob. D. Cito, Questioni sulla prescrizione dell'azione criminale..., s. 40. Davide Cito zmienił, zatem swoje stanowisko w sprawie przerwania biegu przedawnienia. Otóż, aktualnie przyjmuje on w tej sprawie opinię, według której w procesie karnym na drodze sądowej, przerwanie biegu przedawnienia następuje dopiero w momencie wydania wyroku skazującego, a nie jak to wcześniej utrzymywał (oczywiście razem wieloma innymi autorami) w momencie wezwania sądowego. Por. D. Cito, Questioni sulla prescrizione dell'azione criminale (art. 7 m.p. Sacramentorum sanctitatis tutela), w: Quaderni di Ius Missionale 12, La procedura nei delitti riservati alla Congregazione per la Dottrina della Fede, a cura di Claudio Papale, Città del Vaticano 2018, s. 39-40. 
nie zostaje zatem przerwany ani w wyniku wszczęcia czynności dochodzenia wstępnego, ani na skutek wezwania sądowego (bądź przez ordynariusza, jeśli postępowanie toczyć się będzie na drodze administracyjnej), ani dobrowolnego stawienia się stron w sądzie. Wobec powyższego, dochodzenie wstępne oraz wszystkie czynności przed-procesowe ${ }^{29}$ o których w kan. 1717-1719 nie przerywają biegu przedawnienia $^{30}$. Podobnie dzieje się w przypadku czynności procesowych w sensie ścisłym, aż do zakończenia procesu albo poprzez wydanie dekretu końcowego (in via administrativa), albo poprzez wydanie wyroku końcowego (in via iudicialis) ${ }^{31}$.

${ }^{29}$ Nie można mówić o przerwaniu biegu przedawnienia także w przypadkach, kiedy ordynariusz podejmie decyzje przewidziane chociażby w kan. 1341 i kan. 1718 $\S 1$ n. 2. To znaczy, gdyby zarządził, iż nie ma konieczności wszczynania procesu karnego, pomimo tego, że przestępstwo zostałoby faktycznie popełnione.

${ }^{30}$ Dzieje się tak dlatego, ponieważ jesteśmy tutaj na etapie przed-procesowym (proces karny zaczyna się albo w momencie wydania dekretu o wszczęciu procesu karnego na drodze administracyjnej - kan. 1718, 1720, albo w momencie wezwania w procesie karnym na drodze sądowej - kan. 1507-1512; 1721, 1723). Ponadto dochodzenie wstępne może być wszczęte bez indywidualnie oznaczonego sprawcy. Por. D. Cito, La prescrizione in materia penale..., s. 223-224; J. Llobell, dz. cyt., s. 652653. Zob. także, Segnatura Apostolica, Decreto del Prefetto (Card. Agustoni) in Congresso, 22 aprile 1997, Prot. N. 25896/95 CA, w: Frans Daneels, L'imposizione amministrativa delle pene e il controllo giudiziario sulla loro legittimità, w: Processo penale e tutela dei dritti nell'ordinamento canonico, a cura di Davide Cito, Milano 2005, s. 289-301.

${ }^{31}$ Ponieważ przedawnienie biegnie przez cały czas trwania procesu karego, jest zatem możliwe deklarowanie przedawnienia jeżeli skarga kryminalna została wniesiona w odpowiednim czasie. Może się zatem zdarzyć, że istnienie przedawnienia zostanie stwierdzone podczas trwania instancji. Taka sytuacja może być, jak się wydaje spowodowana kilkoma czynnikami. Po pierwsze, może to nastąpić w wyniku zmiany tytułu przestępstwa, podlegającego krótszemu okresowi przedawnienia. Po drugie, może to być zawiązane z późniejszą ustawą przewidującą inny czas przedawnienia. W powyższych przypadkach, chociażby instancja została wniesiona w odpowiednim czasie, to jednak nie może być kontynuowana, z powodu braku tytułu prawnego. Zob. KPK/1983, kan. 1313. 


\section{Dekret i wyrok skazujący jako moment przerwania biegu przedawnienia}

Zarówno w przypadku dekretów jak i wyroków możemy mieć do czynienia $\mathrm{z}$ trzema wariantami podejmowanych decyzji, tzn. $\mathrm{z}$ decyzją która jest: albo absolutoria ab crimine, albo absolutoria ab instantia, albo condemnatoria ${ }^{32}$. Decyzja uwalniająca od przestępstwa jest podejmowana wtedy, gdy ewidentnie stwierdzono, że oskarżony nie popełnił przestępstwa, czyli autor decyzji ma pewność moralną niewinności oskarżonego ${ }^{33}$. Decyzja uwalniająca od instancji jest wydawana wtedy, gdy brakuje wystarczających dowodów na potwierdzenie dokonania przestępstwa. Taka decyzja jest możliwa, gdy jej autor nie osiągnął wymaganej pewności moralnej ani w tym, co się odnosi do winy oskarżonego, ani w tym, co się odnosi do jego niewinności ${ }^{34}$. I w końcu, decyzja może być skazująca, na mocy której następuje wymierzenie albo deklaracja kary w zależności od rodzaju

\footnotetext{
${ }^{32}$ Por. Suprema Sacra Congregatio Sancti Officil, Instuctio Crimen sollicitationis, Ad omnes Patriarchas, Archiepiscopos aliosque locorum Ordinarios „etiam Ritus Orientalis”: De modo procedendi in causis sollicitationis, 16 martii 1962, Typis Polyglottis Vaticanis MCMLXI. Zob. także CH.J. ScICluna, Delicta graviora. Ius processuale, w: Questioni attuali..., s. 86.

${ }^{33}$ Zob. KPK/1983, kan. 1726. Taka sytuacja może wynikać oczywiście z tego, że przestępstwo, tzn. zewnętrzne naruszenie w ogóle nie zostało popełnione, albo zostało popełnione, ale przez osobę nie podlegającą karze. Ponadto może mieć miejsce brak elementu psychologicznego (elementu subiektywnego przestępstwa), albo mogą zaistnieć elementy wyłączające poczytalność (kan. 1323), albo nastąpiła zmiana ustawy karnej, na mocy której naruszenie nie jest już więcej przestępstwem (kan. $1313 \$ 2$ ),

${ }^{34}$ Chodzi zatem o te sytuacje, kiedy zebrane dowody są, według sędziego, nie wystarczające do uznania oskarżonego za winnego i odpowiedzialnego za przypisywane mu fakty - actore non probante reus absolvitur. Inaczej ma tutaj miejsce decisio/sententia dimissoria si autor ex defectu probationum sit invincibiliter dubius. W takim przypadku, zgodnie z kan. $1608 \$ 4$, należy dokonać dimissio sprawy wniesionej przeciwko oskarżonemu. Por. CH.J. Scicluna, Delicta graviora. Ius processuale, w: Questioni attuali..., s. 86.
} 
kary przewidzianej za określone przestępstwo. W tym przypadku autor decyzji ma pewność moralną winy sprawcy ${ }^{35}$.

Kanoniczny proces karny in via administrativa, czy inaczej per decretum extra iudicium ${ }^{36}$ oznacza, że działając na drodze administracyjnej sprawa jest rozpatrywana extra iudicium, poza trybunałem a nie coram tribunali. Działanie poza sądem oznacza, że nie muszą w nim uczestniczyć takie określone osoby jak: sędzia we właściwym znaczeniu; rzecznik sprawiedliwości. Ponadto nie muszą być też zachowywane wszystkie wymogi formalne przewidziane dla procesów przez Księgę VII KPK/1983. Niemniej jednak pewne fundamentalne formalności muszą być zachowane, np. prawo oskarżonego do właściwej obrony; prawo odwołania się do wyższego przełożonego. Chodzi o takie wymogi formalne, od których nie można dyspensowaćs ${ }^{37}$.

\footnotetext{
${ }^{35}$ Por. D. Borek, Przestęstwa zastrzeżone dla Kongregacji Nauki Wary (Normy materialne i procesowe), Tarnów 2019, s. 184-185.
}

${ }^{36}$ Zarówno KPK/1983 (kan. 1720, 1342) jak i Normy z 2010 roku używają tutaj sformułowania dekret pozasądowy. Zgodnie z kan. 1342: „poena irrogari vel declarari potest per decretum extra iudicium". Podobnie stwierdza się w kan. 1720: "Si Ordinarius censuerit per decretum extra iudicium esse procedendum". To samo sformułowanie pojawia się w Normach de delictis reservatis z 2010r., art. $21 \S 2$ : "Attamen Congregationi pro Doctrina Fidei licet: 1 in singulis casibus, ex officio seu ex instantia Ordinarii vel Hierarchae, decernere ut per decretum extra iudicium de quo in can. 1720 Codicis Iuris Canonici et in can. 1486 Codicis Canonum Ecclesiarum Orientalium procedatur; ea tamen mente ut poenae expiatoriae perpetuae solummodo de mandato Congregationis pro Doctrina Fidei irrogentur".

${ }^{37}$ Administracyjne wymierzanie sankcji karnych nabrało w ostatnich czasach szczególnego znaczenia ze względu na uprawnienia przyznane przez papieża Benedykta XVI różnym dykasteriom Kurii Rzymskiej: Kongregacji Nauki Wiary, Kongregacji ds. Duchowieństwa, Kongregacji ds. Ewangelizacji Narodów. Na mocy przyznanych uprawnień istnieje dzisiaj możliwość wymiaru kar wiążących na stale także na drodze administracyjnej. Zob. LLOBELL J., Il giusto processo penale nella Chiesa e gli interventi (recenti) della Santa Sede, Archivio Giuridico 232 (2012) nr 2, s. 181; V. MoscA, Le facoltà speciali concesse alla Congregazione per l'evangelizzazione dei Popoli e alla Congregazione per il Clero (in particolare circa la dimissione dalla condizione giuridica clericale in poenam ed ex officio per via amministrativa), Quaderni di Ius Missionale 3, I delitti riservati alla Congregazione per la Dottrina della Fede, a cura di Andrea D’Auria - Claudio Papale, Roma 2014, s. 159-180. 
A zatem dekret karny, kończący postępowanie karne na drodze administracyjnej, dopiero wtedy będzie skutkował ewentualnym przerwaniem biegu przedawnienia, kiedy stanie się prawomocny. Innymi słowy, jeśli zostaną wyczerpane przewidziane w prawie środki odwołania albo jeśli zainteresowani nie skorzystali z przysługujących im uprawnień.

Zgodnie z kan. 1720, n. 3: „si de delicto certo constet neque actio criminalis sit extincta, decretum ferat ad normam cann. 1342-1350, expositis, breviter saltem, rationibus in iure et in facto". W myśl takiego zapisu przedawnienie płynie w sposób nieprzerwany także podczas całej procedury administracyjnej, aż do momentu uprawomocnienia się dekretu skazującego. Po upływie, czasu przewidzianego dla przedawnienia actio criminialis w przypadku określonego przestępstwa, dekret nie może być wydany ${ }^{38}$. Jak zauważa D. Cito, biorąc pod uwage wyjątkowy charakter procedury administracyjnej, która może być realizowana stosunkowo szybko, oraz przy minimalnej gwarancji praw osoby oskarżonej, wydaje się że taka właśnie interpretacja jest najbardziej odpowiednia właśnie do tego sposobu postępowania. Można zatem przyjąć, że z treści kan. 1720, n. 3 wynika, że aż do momentu wydania dekretu kończącego „pierwszą instancję” bieg przedawnienia nie ulega przerwaniu ${ }^{39}$. Należy jednak zauważyć, że z treści kan. 1720, n. 3 wcale nie wynika, że jakakolwiek decyzja - skazująca lub uwalniająca - miałaby powodować przerwanie biegu przedawnienia skargi kryminalnej, albo wręcz jej wygaśnięcie. W przypadku decyzji skazującej, ewentualne wygaśnięcie skargi kryminalnej oznaczałoby brak możliwości wniesienia rekursu hierarchicznego do przełożonego wyższego albo przeprowadzenia procesu sporno-administracyjnego

Pomimo szczególnych uprawnień dotyczących wymiaru kar na drodze procesu karno-administracyjnego, należy uznać iż nadal via iudicialis jest obowiązkowym/ preferowanym sposobem wymiaru/deklarowania kar w Kościele. Por. KPK/1983, kan. 1342; Normy de delictis reservatis z 2010r., art. 21.

${ }^{38}$ D. Ciтo, La prescrizione in materia penale..., s. 224.

${ }^{39}$ Por. L. LlobelL, dz. cyt., s. 652. 
w Sygnaturze Apostolskiej ${ }^{40}$. W przypadku decyzji uwalniającej z powodu ewentualnego wygaśnięcia skargi, wynikałoby iż przełożony nie mógłby działać ex officio na mocy kan. 1739. Tak naprawdę z treści kan. 1720, n. 3 wynika jedynie to, że decyzja skazująca (si de delicto certo constet) może być wydana jedynie wtedy, kiedy z pewnością stwierdzi się, iż skarga kryminalna nie wygasła w momencie podejmowania tejże decyzji, pomimo braku przerwy w czasie przeprowadzania procesu ${ }^{41}$.

Podobnie rzecz ma się w przypadku procesu karnego in via iudicialis kończącego się wdaniem wyroku. W postępowaniu karnym in via iudicialis, a więc na drodze sądowej istnieje wyraźne rozdzielenie poszczególnych funkcji procesowych: część wprowadzająca (w postaci skargi oskarżającej, ustanowienia trybunału, formalnego wezwania, zawiązania sporu), instrukcja procesu (zebranie dowodów, przesłuchanie oskarżonego, ogłoszenie akt i zamknięcie postępowania dowodowego, dyskusja sprawy), faza decyzyjna (wyrok uwalniający

${ }^{40}$ Zgodnie z kan. 1734, zanim wniesie się rekurs, powinno się najpierw na piśmie prosić autora o odwołanie lub poprawienie dekretu (tzw. rekurs remonstracji); rozumie się, że wniesienie takiej prośby jest przez to samo także prośbą o zawieszenie dekretu. Taką prośbę należy złożyć w terminie zawitym dziesięciu użytecznych dni od zawiadomienia o dekrecie, zgodnie z przepisami prawa. Władza, do której dotarła taka prośba posiada, zgodnie z kan. 1735, trzydzieści dni na udzielenie odpowiedzi na powyższy rekurs. Jeżeli w ciągu trzydziestu dni, od kiedy doszła do autora dekretu prośba, o której w kan. 1734, nie zawiadomi on o nowym dekrecie, w którym albo poprawia pierwszy, albo decyduje, że należy odrzucić prośbę, terminy do wniesienia rekursu biegną od zawiadomienia o nowym dekrecie; jeśli zaś w ciągu trzydziestu dni nie podjął żadnej decyzji, terminy biegną od trzydziestego dnia. Następnie zainteresowany, zgodnie z kan. $1737 \$ 1$, ma piętnaście dni na złożenie rekursu hierarchicznego. Rekurs hierarchiczny należy zatem wnieść w zawitym terminie piętnastu użytecznych dni, które w wypadkach, o których w kan. $1734 \$ 3$, biegną od dnia zawiadomienia o dekrecie, w pozostałych zaś wypadkach, biegną według przepisu kan. 1735. Ostatnim etapem odwołania się jest wniesienie rekursu do Sygnatury Apostolskiej w terminie sześćdziesięciu dni od dnia powiadomienia o odpowiedzi na rekurs hierarchiczny. Benedictus XVI, Liettra apostolica motu proprio data, Antiqua ordinatione 21.06.2008, Art. $74 \S 1$, AAS 100 (2008), s. 513-538.

${ }^{41}$ J. LlobelL, dz. cyt., s. 653. 
albo skazujący) oraz apelacja ${ }^{42}$. Jeżeli zatem ordynariusz zdecydował o wszczęciu procesu karnego na drodze sądowej, powinien przekazać akta dochodzenia rzecznikowi sprawiedliwości, który od tej pory będzie występował w roli strony powodowej, a więc oskarżającej w procesie karnym sądowym (kan. $1721 \$ 1$ ). Tak skonstruowany proces karny sądowy, owszem, wymaga zespołu osób odpowiednio przygotowanych jak również dłuższego czasu, niemniej jednak stwarza lepsze możliwości dojścia do prawdy materialnej i uzyskania rozstrzygnięcia sprawy zgodnie z wymogami sprawiedliwości ${ }^{43}$. Przyjmuje się zatem, że proces karny sądowy, będąc bardziej sformalizowany, oferuje większe gwarancje obiektywności i niezależności wyników postępowania, jak również stwarza lepsze warunki do obrony. Nie można jednak nie dostrzegać i innych elementów mogących przemawiać na niekorzyść procesu karnego sądowego. Takimi elementami mogą być: czas trwania procesu, opóźnienia, rozgłos i ewentualnie niebezpieczeństwo naruszenia czyjegoś dobrego imienia ${ }^{44}$. Zgodnie z cytowanym już kan. 1726, żadna z czynności procesowych uprzednia do wyroku końcowego nie powoduje przerwy biegu przedawnienia, ponieważ przedawnienie actio criminali et poenalis może nastąpić „in quolibet poenalis iudicii gradu et stadio".

Należy zauważyć, że postępowanie sądowe może się nie zakończyć $\mathrm{w}$ momencie wydania wyroku z powodu wniesienia apelacji a to ze względu na skutki jakie ona ze sobą pociąga ${ }^{45}$. Po pierwsze, wniesienie

\footnotetext{
${ }^{42}$ Por. J. Syry JCZy K, Niektóre gwarancje sprawiedliwego wymiaru kar w Kodeksie Prawa Kanonicznego z 1983 r., Prawo Kanoniczne 34 (1991) nr 3-4, s. 150.

${ }^{43}$ Por. tamże, s. 151.

${ }^{44}$ Por. V. De Paolis, L'applicazione della pena canonica, w: Comunità ecclesiale e devianza. Funzione della sanzione penale nell'Ordinamento Canonico, Città del Vaticano 1998, s. 90; Z. Suchecki, Il processo penale giudiziario, w: Il porcesso penale canonico (a cura di) Z. Suchecki, Roma 2003, s. 276-277.

${ }^{45}$ Zgodnie z kan. 1630 apelację należy zgłosić sędziemu (interpositio), który wydał wyrok (a quo), w zawitym terminie piętnastu dni użytecznych od wiadomości o ogłoszeniu wyroku, jeżeli jest ustna, notariusz winien ją zredagować na piśmie wobec samego apelującego. Według Norm de delictis reservatis z 2010 roku na interpositio jest przewidziany miesiąc, a więc $30 \mathrm{dni}$ (zob. Normy, de delictis reservatis z 2010 r., por. art. 18). Następnie apelację należy poprzeć u sędziego (prosecutio),
} 
apelacji od wyroków karnych zwiesza wykonanie takich wyroków ${ }^{46}$. Oprócz tego efektem wniesionej apelacji jest przekazanie sprawy do wyższej instancji, co oznacza, że nie można dopuścić nowego tytułu roszczenia (nie może być na tym etapie wprowadzona nova causa petendi) ${ }^{47}$. Zawiązanie sporu odnosi się tylko do tego, czy poprzedni wyrok, czy to w całości czy częściowo, zatwierdzić czy odrzucić. Należy jednak zaznaczyć, że tantum devolutum, quantum appellatum, czyli że zakres kompetencji sędziego drugiej instancji jest uzależniony

do którego jest kierowana (ad quem), w ciągu miesiąca od jej zgłoszenia, chyba że sędzia, od którego się apeluje, udzielił stronie dłuższego terminu do jej poparcia.

${ }^{46} \mathrm{KPK} / 1983$, kan. 1638; 1353. Osobami uprawnionymi do wniesienia apelacji będą strony procesu karnego, a więc rzecznik sprawiedliwości oraz oskarżony. Można sobie zadać pytanie odnośnie do tego, czy w procesach karnych in via iudicialis taką apelację będzie mogła wnieść ewentualnie ofiara przestępstwa, występująca w procesie jako świadek, która jak wiadomo jest w sposób szczególny zainteresowana wynikiem procesu. Wydaje się, że nie będzie takiej możliwości, ponieważ nie jest ona stroną postępowania, chyba że zostałaby do takiego procesu włączona w związku z wniesieniem skargi o naprawienie szkód w myśl kan. 1729-1731, lub na podstawie kan. 1596 jako strona wspomagająca jedną ze stron, czyli w tym przypadku rzecznika sprawiedliwości. Por. D. BoreK, Przestępstwa zastrzeżone dla Kongregacji Nauki Wary..., s. 232-234. Wydaje się, że takie włącznie świadka będącego ofiarą/ poszkodowanym jako stronę wspomagającą rzecznika sprawiedliwości jest jak najbardziej uzasadnione - jej prawo do interwencji wynikałoby z tego, iż to właśnie taka osoba jest najbardziej zainteresowana tym, aby sprawca przestępstwa został pociągnięty do odpowiedzialności, ponieważ to przede wszystkim ona doznała szkody. Przykładowo, zatem taka osoba mogłaby być zainteresowana wniesieniem apelacji w przypadku wyroku uwalniającego oskarżonego od instancji z powodu braku wystarczających dowodów. Taki interwenient mógłby zatem zostać włączony do procesu, aby wspierać rzecznika sprawiedliwości i tym samym stać się stroną $\mathrm{w}$ toczącym się procesie w pełnym tego słowa znaczeniu. Por. C. PAPALE, I processi. Commento ai canoni 1400-1670 del Codice di Diritto Canonico, Città del Vaticano 20116, s. 323-325; zob. także A.G. MizıŃsKi, Strony w kanonicznym procesie karno-sądowym według aktualnych przepisów Kościoła łacińskiego, Teka Kom. Praw. - OL PAN, 2010, s. 127.

${ }^{47}$ Normy de delictis reservatis z 2010 roku, art. 23: „Jeśli na stopniu apelacyjnym rzecznik sprawiedliwości wnosi oskarżenie specyficznie odmienne, ten Najwyższy Trybunał może je przyjąć i rozpatrywać, tak jakby to było w pierwszej instancji”. 
od zakresu wniesionej apelacji (por. kan. $1637 \$ 3)^{48}$. Dopiero po wyczerpaniu wspominanych wyżej możliwości odwołania możemy mówić o prawomocności wyroku ${ }^{49}$. W przypadku apelacji wyrok będzie prawomocny, a więc będzie można zająć się jego wykonaniem, jeśli zapadną dwa wyroki zgodne $e^{50}$. Natomiast w przypadku zaniechania

${ }^{48}$ Można zadać sobie pytanie, czy na płaszczyźnie prawa kanonicznego, w kontekście podejmowania decyzji przez sędziego ad quem apelacji, istnieje zakaz reformatio in peius decyzji sędziego a quo? Z pewnością zakaz reformatio in peius nie mógłby dotyczyć apelacji wniesionych przez rzecznika sprawiedliwości, w przeciwnym razie mielibyśmy do czynienia z ograniczeniem fundamentalnych praw i zadań rzecznika sprawiedliwości. Można natomiast rozważać możliwość zastosowania zakazu reformatio in peius w przypadku apelacji wniesionej przez oskarżonego/ skazanego, gdyż taki zakaz oznaczałby zastosowania rozwiązania korzystniejszego dla winnego. Takie ustawienie sprawy byłoby zgodne z ogólną linią zastosowania korzystniejszych rozwiązań w odniesieniu do winnego, widocznych m.in. w następujących przypadkach: in dubbio pro reo; zastosowanie ustawy korzystniejszej dla sprawcy w przypadku kolizji ustaw karnych (kan. 1313); złagodzenia kar w słusznych granicach w przypadku kumulacji przestępstw (kan. 1346). Należy, jednakże zaznaczyć, że KPK/1983 nigdzie nie przewiduje takiego zakazu. Być może zatem należałoby przyjąć, że trybunał wyższej instancji może - także w przypadku delicta reservata - podjąć decyzję, która będzie oznaczała pogorszenie sytuacji oskarżonego/winnego w porównaniu z wyrokiem trybunału pierwszej instancji, niezależnie od tego kto wniósł apelację. Por. C. PAPAle, Il processo penale canonico..., s. 158; Zob. także, A. D'Auria, Causa petendi e reformatio in peius: alcune considerazioni sul can. 1739, Periodica 96 (2007) n. 2, s. 249-284.

${ }^{49}$ Oczywiście w przypadku wniesienia apelacji, czy to przez oskarżonego czy przez rzecznika sprawiedliwości, o prawomocności wyroku będziemy mówili w przypadku dwóch zgodnych wyroków. Por. A. Calabrese, Diritto penale canonico, Città del Vaticano 1996, s. 214-215.

${ }^{50}$ Por. KPK/1983, kan. 1641, n. 1; $1650 \$ 1$. Będzie można mówić o wyrokach zgodnych, jeśli zapadły dwa zgodne wyroki między tymi samymi stronami, co do tego samego żądania (petitum) i z tego samego tytułu roszczenia (causa petendi). Należy w tym miejscu zaznaczyć, że nie zawsze dwa wyroki zgodne wydane w sprawach karnych, będą oznaczać, że sprawa przeszła w stan rzeczy osądzonej. Faktycznie bowiem sprawy, które dotyczą stanu osób nie przechodzą w stan rzeczy osądzonej (KPK/1983, kan. 1643). Wydaje się, że w przypadku kary wydalenia ze stanu duchownego możemy mówić właśnie o wyroku, który dotyczy stanu osób. W takich przypadkach wyrok skazujący na karę wydalenia ze stanu duchownego nie przechodzi w stan rzeczy osądzonej. W takich przypadkach należy - zgodnie z kan. 1643 - przyjąć, 
wniesienia apelacji wyrok będzie prawomocny w zależności od formy tegoż zaniechania. Otóż zaniechanie może być milczące, to znaczy następujące po bezużytecznym upływie apelacyjnych terminów zawitych, czy wobec sędziego, który wydał wyrok, czy wobec sędziego apelacyjnego, apelację uważa się za zaniechaną ${ }^{51}$. Ponadto zaniechanie może być także wyraźne ${ }^{52}$, to znaczy w przypadku zrzeczenia się apelacji wraz ze skutkami, o których mowa w kan. $1525^{53}$.

Dopóki zatem dekret/wyrok się nie uprawomocni, to cały czas bieg przedawnienia nie zostaje przerwany. Innymi słowy, rekurs i apelacja skutkują tym, że przedawnienie cały czas płynie, ponieważ dekret i wyrok ulegają zawieszeniu (kan. 1353). Jeśli więc, okazałoby się że w trakcie rozpatrywania rekursu/apelacji nastąpiłoby przedawnienie actio criminalis to $\mathrm{w}$ takim razie oskarżony powinien zostać uwolniony $\mathrm{z}$ powodu przedawnienia, nawet jeśli byłoby pewne, że

że wyrok nie przechodzi w stan rzeczy osądzonej. Por. Tribunale Apostolico Della Rota Romana, Dimissione dallo stato clericale, Ius Ecclesiae 7 (1995), s. 672-673; H. FRANCESCHI, L'impugnazione del giudicato nel processo penale: <restitutio in integrum $>$ o $<$ nova causae propositio $>$, Ius Ecclesiae 7 (1995), s. 683. Por. także, A. Calabrese, dz. cyt., s. 215. Odmienne stanowisko prezentuje J. Llobell, według którego nawet te sprawy które dotyczą wydalenia ze stanu duchownego, czy też wydalenia z instytutu zakonnego, nie należą do spraw dotyczących stanu osób, i tym samym przechodzą w stan rzeczy osądzonej. Por. L. Llobell, dz. cyt., s. 649650. W myśl takiego założenia sprawy karne przechodzą w stan rzeczy osądzonej zgodnie z tym, co się przewiduje w kan. 1641. Pewną trudnością może być sytuacja wynikająca z prawa do dwóch zgodnych wyroków (można jako przykład podać sytuację oskarżonego, który zaskarżył wcześniejszy wyrok ponieważ niezgodny z poprzednim). Otóż do czasu osiągnięcia takich wyroków, nie można mówić o res iudicata, a zatem i o ewentualnym przerwaniu/zawieszeniu biegu przedawnienia. W związku z czym może stosunkowo łatwo dojść do przedawnienia actio criminalis. Problem ten rozwiązano w przypadku delicta reservata, zgodnie bowiem $\mathrm{z}$ Normami de delictis reservatis z 2010 roku, art. 28 n. 1, wyrok przechodzi w stan rzeczy osądzonej, jeżeli został wydany wyrok w drugiej instancji. A zatem niezależnie od tego, czy jest zgodny z poprzednim, czy też nie. Takie rozwiązanie byłoby także dobre w odniesieniu do wszystkich spraw karnych. Por. L. LlobelL, dz. cyt., s. 656.

${ }^{51} \mathrm{KPK} / 1983$, kan. 1635.

${ }^{52}$ KPK/1983, kan. 1636.

${ }^{53}$ Por. A. Calabrese, dz. cyt., s. 215. 
popełnił on przestępstwo (kan. 1726) ${ }^{54}$. Przerwa biegu przedawnienia actio criminalis następuje zatem dopiero w momencie uprawomocnienia się dekretu karnego lub wyroku karnego. Będzie tutaj chodziło zarówno o "giudicato materiale" jak o "giudicato formale". W pierwszym przypadku będziemy mieli do czynienia z dekretem/ wyrokiem natury konstytutywnej, który może być wykonany a zaskarżany jedynie przez restitutio in integrum. Natomiast w drugim z przypadków mamy do czynienia $\mathrm{z}$ dekretem/wyrokiem w sprawach dotyczących stanu osób. Chodzi zatem o decyzje o charakterze czysto deklaratywnym, które mogą być wykonane, a zaskarżane jedynie poprzez nova causae propositio ${ }^{55}$.

Tak więc favor rei prowadzi do wniosku, że żadna czynność procesowa uprzednia do dekretu/wyroku definitywnego nie przerywa ani nie zawiesza biegu skargi kryminalnej. Natomiast actio ad poenam exsequendam $\mathrm{z}$ natury swej wymaga tego, aby decyzja skazująca wywoływała skutek w postaci przerwy lub zawieszenia skargi penalnej ${ }^{56}$.

Należy pamiętać o tym, że nie będzie mowy o przerwie skargi ad poenam exsequendam w przypadku, kiedy dekret/wyrok wprawdzie przeszedł w stan rzeczy osądzonej, ale ordynariusz/sędzia zawiesił wykonanie dekretu/wyroku ze względu na okoliczności, o których mowa w kan. 1344, n. 3. Ponadto nie może być mowy o przerwie ww. skargi w przypadku, jeśli nie przystąpiono do wykonania kary, ponieważ skazany nie został, bez winy z jego strony, powiadomiony o dekrecie wykonawczym (kan. 1363, 1651). Podobnie rzecz się ma wtedy, kiedy pomimo uprzedniego powiadomienia skazanego o dekrecie wykonawczym, władza nie przystąpiła do wykonania zgodnie z tym, co się przewiduje w kan. 1653 i $1654^{57}$.

Przyjmując zatem, że przerwa biegu przedawnienia następuje dopiero z chwilą, kiedy dekret/wyrok przechodzi w stan rzeczy osądzonej, okazuje się że stosunkowo szubko i łatwo może dojść do

\footnotetext{
${ }^{54}$ L. LlobelL, dz. cyt., s. 655.

${ }^{55}$ Tamże, s. 650, przypis n. 35.

56 Tamże, s. 652.

57 Tamże, s. 659.
} 
przedawnienia i w związku z tym do sytuacji, kiedy winny nie będzie mógł zostać pociągnięty do odpowiedzialności karnej ${ }^{58}$. Taka sytuacja, z punktu widzenia bonum commune Ecclesiae może być bardzo szkodliwa. Niezbędne jest zatem wprowadzenie koniecznych zmian, które regulowałby właśnie kwestię przerwania i/lub zawieszenia biegu przedawnienia inaczej niż jest to robione aktualnie ${ }^{59}$. Wprowadzenie instytucji przerwy/zawieszenia biegu przedawnienia w innym momencie, aniżeli jest to przewidziane aktualnie, wydaje się być jak najbardziej uzasadnione. Wydaje się, że takim najbardziej właściwym momentem byłoby pierwsze wezwania oskarżonego (zarówno na drodze sądowej jak i administracyjnej). Jednocześnie należałoby jednak wprowadzić określony termin, w przeciągu którego sprawa powinna zostać rozstrzygnięta. W przeciwnym razie, licznik biegu przedawnienia wznowi swoją pracę i bieg przedawnienia będzie kontynuowany ${ }^{60}$.

\footnotetext{
${ }^{58}$ Warto w tym miejscu zwrócić jeszcze uwagę na skutki, jakie przedawnienie actio criminalis ma w odniesieniu do środków zapobiegawczych z kan. 1722. Otóż, jak przypomina L. Llobell, favor rei oraz zasady wyrażone w kan. 18 i 19 domagają się, aby postanowienia zapobiegawcze z kan. 1722 mogły być stosowane jedynie w ramach procesu karnego na drodze sądowej. Innymi słowy terminem początkowym (a quo) zastosowania tychże postanowień byłby moment wszczęcia procesu, a terminem końcowym (ad quem) z kolei moment zakończenie procesu w wyniku przejścia sprawy w stan rzeczy osadzonej lub właśnie w wyniku przedawnienia skargi kryminalnej. Tak więc przedawnienie actio criminalis będzie miało także wpływ na ustanie postanowień z kan. 1722, które nie mają charakteru karnego, ale raczej dyscyplinarny. L. LLOBELL, dz. cyt., s. 657-658.

${ }^{59}$ Jak to było wspomniane w niniejszym artykule, w doktrynie wskazywano, że taka przerwa biegu przedawnienia ma miejsce, albo w momencie wszczęcia dochodzenia wstępnego (kan. 1717), albo w momencie wezwania oskarżonego (kan. 1512, n. 4), albo w momencie decyzji w „pierwszej instancji” w procesie na drodze administracyjnej, lub w momencie zastosowania postanowień z kan. 1722. Oczywiście takie rozwiązania należałoby traktować raczej w kategorii postulatów/propozycji a nie faktycznie istniejącego już rozwiązania prawnego. Dla wszystkich ww. rozwiązań nie znajdujemy bowiem żadnych argumentów kanonicznych. L. LLobeLL, dz. cyt., s. 660 .

${ }^{60}$ Chodzi bowiem o to, aby uniknąć ewentualnych nadużyć które polegałyby na nieuzasadnionym przedłużaniu procesów, czy chociażby nieograniczonego w czasie trwania postanowień zapobiegawczych z kan. 1722. L. LlobelL, dz. cyt., s. 660.
} 
Podsumowując należy stwierdzić, że w obowiązujących przepisach prawa kanonicznego odnoszących się do przerwy biegu przedawnienia przewage znajduje raczej favor rei, a nie bonum commune Ecclesiuae znajdujące wyraz w ius puniendi. Dopiero bowiem decyzja skazująca (zarówno ta sądowa jak i administracyjna), która staje się sprawą osądzoną (res iudicata), zawiesza bieg przedawnienia skargi kryminalnej. Taka sytuacja oznacza, że prawo kanoniczne dopuszcza dzisiaj możliwość uniknięcia odpowiedzialności karnej sprawców przestępstw kanonicznych tylko i wyłącznie z powodu upływu czasu przewidzianego na wygaśnięcie skargi kryminalnej, a jak wiadomo z zasady terminy są tutaj stosunkowo krótkie. Jak zauważa J. Llobell taka sytuacja powinna zostać jak najszybciej zmieniona, niemniej jednak należałoby unikać takich interpretacji procedury karnej (sądowej i administracyjnej), które byłyby w jawnej sprzeczności z zasadą favor rei i zasadami hermeneutyki wyrażonymi w kan. 18 i 19 KPK/1983 ${ }^{61}$.

\section{Wnioski}

W związku z pewną luką jaka ma właściwie miejsce w odniesieniu do przerwy biegu przedawnienia actio criminalis i actio poenalis wydawałoby się jak najbardziej uzasadnione, aby zaradzić takiej luce poprzez wprowadzenie zapisu zgodnie z którym przerwa następowałaby w momencie wezwania sądowego lub stawienia się stron w sądzie. Takie rozwiązanie nie byłoby jednak wolne od pewnych mankamentów. Otóż, jeśli przerwanie biegu przedawnienia miałoby nastąpić w momencie wezwania sądowego lub dobrowolnego stawienia się stron w sadzie, to oznaczałoby to, że dalsze czynności procesowe mogą być przeprowadzane bez konieczności zwracania uwagi na przedawnienie, ponieważ jego bieg został przerwany. Innymi słowy sędzia może podjąć decyzję niezależnie do tego, czy w trakcie trwania czynności procesowych minął już okres przewidziany dla przedawnienia w przypadku określonego przestępstwa. Z drugiej, jednakże strony takie rozwiązanie oznaczałoby przyjęcie przez ustawodawcę kodeksowego rozwiązania będącego na niekorzyść zasady favor rei

\footnotetext{
${ }^{61}$ J. LLOBELL, dz. cyt., s. 643.
} 
znajdującej wyraz chociażby w stosunkowo krótkich terminach przedawnienia actio criminalis. Rozwiązaniem, które pozwoliłoby na ewentualne wyrównanie napięcia pomiędzy favor rei i bonum commune byłoby wprowadzenie przez ustawodawcę kościelnego bardziej szczegółowych zmian dotyczących wydłużenia okresów przedawnienia, ścisłego sprecyzowania momentu, który następowałoby wstrzymanie biegu przedawnienia, oraz zmiany instytucji przerwy na instytucję zawieszenia biegu przedawnienia.

Po pierwsze wydaje się rzeczą jak najbardziej wskazaną, aby nastąpiło wydłużenie czasu przedawnienia prawa ścigania (actio criminalis). Za takim postulatem przemawia chociażby fakt wydłużenia czasu przedawnienia w przypadku dalicta graviora, który to czas początkowo wynosił dziesięć lat a od 2010 roku dwadzieścia. Nie bez znaczenia pozostaje tutaj także kwestia związana $\mathrm{z}$ uprawnieniem przysługującym Kongregacji Nauki Wiary do uchylenia przedawnienia. Doświadczenia ostatnich dekad pokazują, że Kongregacja często z tego upoważnienia korzysta. Oczywiście ewentualne wydłużenie czasu przewidzianego na przedawnienie karalności powinno dotyczyć szczególnie tych przestępstw, które można by zaliczyć do kategorii szczególnie ciężkich ze względu na przedmiot którego dotyczą oraz reperkusje społeczne.

Po drugie, w celu uniknięcia wątpliwości, a więc dla zagwarantowania właściwego wymiaru sprawiedliwości niezbędne wydaje się także wyraźne wskazanie na to, kiedy właściwie następuje przerwanie/zawieszenie biegu przedawnienia oraz oczywiście z jakiego powodu. Należy poprzeć wniosek domagający się tego, aby jako właściwy moment przerwania/zawieszenia biegu przedawnienia wskazać pierwsze wezwanie/powiadomienie oskarżonego z zastosowaniem do obydwu dróg wymiaru/deklarowania kar w Kościele. Z takim ustawieniem sprawy, wiązała by się ponadto konieczność stwierdzenia, że od takiego właśnie momentu byłaby możliwość także zastosowania postanowień zapobiegawczych z kan. 1722, zarówno w procesie karym na drodze sądowej jak i administracyjnej.

Po trzecie, słuszny wydaje się także postulat dokonania zamiany instytucji przerwy na instytucję zawieszenia, która pozwala na 
wznowienie pracy licznika, czyli na kontynuację czasu jaki upłynął do momentu zaistnienia przyczyny zawieszającej bieg przedawnienia. W takim przypadku konieczne byłoby wprowadzenie ściśle kreślonych terminów trwania takiego zawieszenia, różnych w zależności od tego czy będzie to proces karny na drodze sądowej (np. osiemnaście miesięcy) czy administracyjnej (np. dziewięć miesięcy). Analogicznie należałoby zrobić w przypadku zaskarżania wyroków i dekretów. Ponadto, mając na uwadze zasadę iustitia prolungata, iustitia denegata, należałoby także wprowadzić ramy czasowe dla czynności dochodzenia wstępnego, które aktualnie nie jest w żaden sposób ograniczone czasowo.

I w końcu, cenne byłoby także doprecyzowanie przyczyn mówiących o ustaniu skargi kryminalnej analogicznie jak to ma miejsce w kan. $1152 \S 1$ KKKW. Ponadto wskazane byłoby uchylenie przepisu o prawie do podwójnego zgodnego wyroku i wprowadzenie zapisu mówiącego o tym, że wyrok wydany w drugiej instancji kończy sprawę - niezależnie od tego, czy jest zgodny z wyrokiem pierwszej instancji, czy też nie.

\section{The interruption of the course of prescription of a criminal complaint in a canon criminal action}

The institution of prescription belongs to the field of issues rarely discussed by canon law. It is especially true about the interruption (suspension in particular) of the course of prescription.

It should be noticed that the institution of interruption, and especially suspension, is weakly emphasised in both material and formal aspects of canon criminal law. In the context of relatively short terms projected currently for the prescription of actio criminalis, the issue of presumptive interruption (and/or suspension) of prescription becomes substantial.

It should be stressed that the existing canon doctrine presents various opinions on when the proper interruption takes place. Such a lack of cohesion in the opinions forces the author of this article to answer the following questions: Is there any place in the canon law, both material and formal, for the institution of the interruption and/or suspension of prescription? If so, when exactly does it take place? And what effects does it have? 
Trying to find answers to these questions the author focuses on the following issues: general remarks on the interruption and suspension, various opinions on the exact moment the interruption takes place, and the decree/sentence as the moment of interrupting the course of prescription

SŁOWA KLUCZOWE: przedawnienie; przerwa przedawnienia; kanoniczne prawo karne; kanoniczny proces karny; skarga kryminalna; skarga o wykonanie kary; dekret karny; wyrok

KEYwORDs: prescription; interruption of prescription; penal canon law; penal canon process; criminal action; action to execute a penalty; extrajudicial decree; sentence

\section{Nota O AUTORzE}

O. DR hab. DARIUSz Borek, Prof. UCzelni - należy do prowincji pw. św. Józefa w Polsce Zakonu Braci Najświętszej Maryi Panny z Góry Karmel (Karmelici). Od 2001 roku jest zatrudniony na Wydziale Prawa Kanonicznego Uniwersytetu Kardynała Stefana Wyszyńskiego w Warszawie. Jest autorem różnych publikacji - monografii i artykułów - szczególnie z zakresu kanonicznego prawa karnego. 